\title{
Downstream processing of pectinase produced by Aspergillus niger in solid state cultivation and its application to fruit juices clarification
}

\author{
Patrícia POLETTO ${ }^{1 \star}$, Caroline BORSÓI ${ }^{1}$, Mara ZENI ${ }^{1}$, Mauricio Moura da SILVEIRA ${ }^{1}$
}

\begin{abstract}
In this work, a protocol for the formulation of an enzyme concentrated product to be applied in fruit juice treatment is described. Downstream processing conditions for the recovery and concentration of pectinases produced by the new strain Aspergillus niger LB-02-SF in solid state cultivation were assessed. The solid-liquid ratio in the extraction step of pectinases recovery from the cultivated media was evaluated and the highest activity was obtained with a solid-liquid ratio of 1:10. The crude extract was concentrated by ultrafiltration and the total pectinase (TP) activity was 73.6-fold concentrated in relation to the crude extract, and a final TP titer of $663 \mathrm{U} \mathrm{mL}^{-1}$ was obtained with $73.7 \%$ of recovery yield. $\mathrm{KCl}$ and different glycerol concentrations were added to the concentrated extract and the stability of pectinases during the storage at $5^{\circ} \mathrm{C}$ for 59 weeks was tested. The formulation with $50 \% \mathrm{w} / \mathrm{w}$ glycerol was applied to the treatment of apple and grape juices and the results of these tests were statistically comparable to those obtained with two high-quality commercial preparations.
\end{abstract}

Keywords: solid-state cultivation; downstream processing; pectinase stability; pectinase formulation; juice clarification.

Pratical Application: The study characterizes the downstream processing and formulation of pectinases, which are not presented by the producing companies.

\section{Introduction}

Pectinases comprise a group of enzymes that hydrolyze pectic substances present in plant cells. Among the different applications, pectinases are widely used for depectinization of fruit juices (Jayani et al., 2005; Gummadi \& Panda, 2003). Pectinases are mainly produced by filamentous fungi, especially by the genus Aspergillus, in submerged cultivation (SmC) or solid-state cultivation (SSC).

The recovery and concentration steps are important operations in enzyme production processing and may take into account the degree of purity needed for each particular application. Some commercial enzyme preparations consist essentially of concentrated culture broth plus additives to stabilize enzyme activity (European Commission, 2002). For SSC, one must consider that the produced metabolites are retained in a solid matrix and must be solubilized by solid-liquid extraction prior to the subsequent downstream operations. There is no consensus with regard to the ideal strategy to perform this extraction. In fact, different conditions for solid-liquid ratio, solvent, temperature and operation time are reported in the specialized literature (Rodríguez-Fernández et al., 2012; Díaz et al., 2007; Castilho et al., 2000).

In the next downstream step, the solubilized enzymes are subjected to a concentration procedure such as salt and solvent precipitation, two aqueous-phase separation or ultrafiltration, among others (Nakkeeran et al., 2010; Maciel et al., 2014). Ultrafiltration (UF) has been used as an attractive tool for many industrial separation processes and a very common application is in downstream processing for product concentration to remove a buffer or a solvent (Charcosset, 2006). UF-based downstream processing can be advantageous for enzyme separation, especially due to the low temperature of operation and the high separation factor.

In the present work, pectinases produced by SSC with Aspergillus niger LB-02-SF, a new strain isolated by Sandri et al. (2013), was used to develop an enzyme formulation to be used in the treatment of fruit juices. For this purpose, an experimental downstream processing protocol was defined, including conditions for the extraction from the solid media, further activated charcoal and microfiltration treatments to remove impurities and enzyme concentration by ultrafiltration. In the sequence, $\mathrm{KCl}$ and different concentrations of glycerol were evaluated as stabilizer additives for the enzyme preparations. Finally, the efficiency of the experimental formulation was tested in apple and grape juices treatment.

\section{Materials and methods}

\subsection{Microorganism and cultivation conditions}

The strain A. niger LB-02-SF, from the University of Caxias do Sul (Brazil) was propagated in glycerin agar medium and incubated at $30^{\circ} \mathrm{C}$ for 5 days. The sporulated cultures were stored at $4^{\circ} \mathrm{C}$ until the inoculation of culture media. 
The cultivation medium was defined by Fontana et al. (2005): wheat bran (Moinho Nordeste, Brazil), citric pectin (CP Kelco S.A, Brazil), glucose, salt nutrient solution and a volume of suspension of $A$. niger $\left(1 \times 10^{7}\right.$ spores $\left./ g\right)$ in distilled water to reach an initial moisture of $53 \%$.

A. niger LB-02-SF cultivations were carried out in trays with $1460 \mathrm{~g}$ of medium and $4 \mathrm{~cm}$ of height, for $96 \mathrm{~h}$, at $30^{\circ} \mathrm{C}$. The trays were covered with a thin layer of gauze, which allowed gas and heat changes with the external environment by simple diffusion.

\subsection{Extraction conditions}

A. niger-cultivated solid media was homogenized and samples were suspended in distilled water (pH 4.0) in $250 \mathrm{~mL}$ Erlenmeyer flasks that were reciprocally agitated at $200 \mathrm{rpm}$ (B. Braun Biotech model Certomat H, Germany). The extraction time of 15, 30, 60, 90 and 120 minutes was evaluated with a dry solid/liquid $(\mathrm{S} / \mathrm{L})$ ratio of $1 / 15$, at $20^{\circ} \mathrm{C}$. The effect of temperature on the extraction was assessed by incubating the samples in a $\mathrm{S} / \mathrm{L}$ ratio of $1 / 15$, at 20,30 and $40^{\circ} \mathrm{C}$ for 60 minutes. $\mathrm{S} / \mathrm{L}$ ratios of $1 / 5,1 / 7.5,1 / 10,1 / 15,1 / 30$ and $1 / 45$ were tested at the same volume of distilled water $(30 \mathrm{~mL})$ and different mass of solid, at $20^{\circ} \mathrm{C}$ for 60 minutes. The liquid enzymatic extract was separated from the residual solid mass by centrifugation $(6,000 \mathrm{rpm}$ for $10 \mathrm{~min}$ ) and filtered through Whatman $\mathrm{n}^{\circ} 1$ filter paper.

\subsection{Pre-treatment of crude extract with activated charcoal and microfiltration}

The crude extract was pre-treated with activated charcoal at $5 \mathrm{~g} / \mathrm{L}$ for $30 \mathrm{~min}$. The mixture was centrifuged at $6,000 \mathrm{rpm}$ for $10 \mathrm{~min}$ and the supernatant was filtered through Whatman No. 1 filter paper.

Microfiltration (MF) of the activated charcoal-treated enzyme extract was carried out in a hollow fiber polyimide membrane with $0.2 \mathrm{~m}^{2}$ of area and pore size of $0.4 \mu \mathrm{m}$ (PAM Membranas Seletivas, Brazil), at a pressure of $40 \mathrm{kPa}$.

\subsection{Concentration of pectinases by ultrafiltration}

Ultrafiltration operation was performed at $20^{\circ} \mathrm{C}$ using a polyethersulfone spiral wound membrane with $0.1 \mathrm{~m}^{2}$ of area and a nominal molecular cut off of $10 \mathrm{kDa}$ (Millipore, USA), at $100 \mathrm{kPa}$. The performance of UF process was evaluated by the activity concentration ratio (ACR), recovery yield (\%) (Equation 1) and fold purification (Equation 2) as follows (Cheryan, 1998):

Recovery yield $(\%)=\left(\frac{\mathrm{Ac} \times \mathrm{Vc}}{\mathrm{Af} \times \mathrm{Vf}}\right) \times 100$

Fold purification $=\frac{\text { specific activity in the concentrate }}{\text { specific activity in the crude extract }}$

where $\mathrm{Vf}, \mathrm{Vp}$ and $\mathrm{Vc}$ are the volume of feed, permeate and concentrate $(\mathrm{mL}), \mathrm{Af}, \mathrm{Ap}$ and Ac are the enzyme activity of feed, permeate and concentrate $\left(\mathrm{U} \mathrm{mL}^{-1}\right)$, respectively.

\subsection{Formulation of the enzyme preparation}

Glycerol (20, 30, 40 and 50\% w/w) and $\mathrm{KCl}(2 \% \mathrm{w} / \mathrm{w})$ were used as additives in the enzyme formulation. Thermostability of enzyme formulations and the control (without additives) were evaluated at $20,30,40,50$ and $60^{\circ} \mathrm{C}$ by $60 \mathrm{~min}$. The study of shelf life of enzyme formulations and the control was performed during 59 weeks. The samples were stored at $5^{\circ} \mathrm{C}$ and TP activity was measured each 15 days.

\subsection{Juice preparation and enzymatic treatment}

Apple and grape fruits were heating at 35 and $45^{\circ} \mathrm{C}$, respectively for $45 \mathrm{~min}$ and the juices were obtained pressing manually the pulps, filtered and finally enzymatic treated.

Commercial enzymes Pectinex Ultra SP-L and Novozym 33095 were compared with the experimental preparation in the clarification step. The dosage of $25 \mathrm{U}$ of enzyme per $100 \mathrm{~mL}$ was indicated by the manufacture of commercial enzymes. Clarification was done for $45 \mathrm{~min}$ at $35^{\circ} \mathrm{C}$ and $45^{\circ} \mathrm{C}$ to the apple and grape juices, respectively. The juice clarity was determined by the sum of absorbances at 440 and $520 \mathrm{~nm}$ for apple juice and 420, 520 and $620 \mathrm{~nm}$ for grape juice (Rangana, 1977). The juice viscosity was measured at $30^{\circ} \mathrm{C}$ with a viscometer and the turbidity with a turbiditymeter at $23^{\circ} \mathrm{C}$. Total phenols were determined by the Folin-Ciocalteu procedure (Singleton \& Rossi, 1965).

\subsection{Determination of pectinase activity and protein}

Total pectinase (TP) activity was determined by measuring the decrease in viscosity of a citric pectin solution (Gainvors et al., 2000).

Protein was determined by the Bradford method (Bradford, 1976).

\section{Results and discussion}

\subsection{Definition of solid / liquid extraction conditions}

The downstream processing, firstly involved the extraction of enzymes from the solid media in order to achieve a solution with enzyme activities as high as possible. In these tests, total pectinase activity (TP) and protein concentration were used as evaluation parameters.

In standard conditions, no significant differences were observed when the time of extraction varied from 15 to 60 minutes. For all times, TP activity of $5.5 \mathrm{U} \mathrm{ml}^{-1}$ and protein concentration of $100 \mu \mathrm{g} \mathrm{ml}^{-1}$ were measured. This result could be important in an industrial point of view, because in a few minutes the extraction step could be completed.

When extraction temperatures of 20,30 and $40^{\circ} \mathrm{C}$ were evaluated, a decrease of $42 \%$ in TP activity was observed at $40^{\circ} \mathrm{C}$ when compared to $20^{\circ} \mathrm{C}$ (Figure 1). Díaz et al. (2007), suggest that at higher temperatures the saturation of the solvent by a number of other compounds present in the media occurs, and that makes the enzyme extraction less efficient. However, no significant difference was noticed with respect to protein concentration at the different temperatures (Figure 1), and it is possible that a partial inactivation of enzyme occurred due to the combination of a higher temperature and the time of incubation. 
Mohsen et al. (2009) [30] and Hendges et al. (2011), reported that pectinases produced by different strains of $A$. niger have shown to be almost completely stable at temperatures up to $30^{\circ} \mathrm{C}$, but their activities have been reduced to approximately $60 \%$ and $80 \%$ of the initial, respectively, after exposed to a temperature of $40^{\circ} \mathrm{C}$ for 60 minutes.

The best results for TP activity recovery per gram of dry solid medium was obtained with an $\mathrm{S} / \mathrm{L}$ ratios of $1 / 30$ and $1 / 45$ (Table 1). On the other hand, with $\mathrm{S} / \mathrm{L}$ ratios of $1 / 5$ and $1 / 7.5$, TP recovery decreased significantly. The results can be explained by the fact that these tests were performed with $74 \%$ moist medium, although S/L ratios are expressed in dry medium basis. That means that approximately $3.8 \mathrm{~g}$ of moist medium had to be used to have $1.0 \mathrm{~g}$ of dry medium. As such, with $\mathrm{S} / \mathrm{L}$ of $1 / 5$ and $1 / 7.5$, the volume of solvent was insufficient for enzyme extraction. When the TP extraction was evaluated taking into account enzyme units recovered per $\mathrm{mL}$ of solvent, the most concentrated activity solution was achieved with $\mathrm{S} / \mathrm{L}$ of $1 / 10$ ratio. Despite the fact that TP recovery with S/L of $1 / 10$ was approximately $80 \%$ of that obtained with S/L of $1 / 45$, this condition was chosen for downstream processing, because the greater the enzyme activity in the crude extract, the lower the initial volume to be concentrated and the time necessary to reach the desired activity of the concentrated extract. Rodríguez-Fernández et al. (2012), studied the extraction of

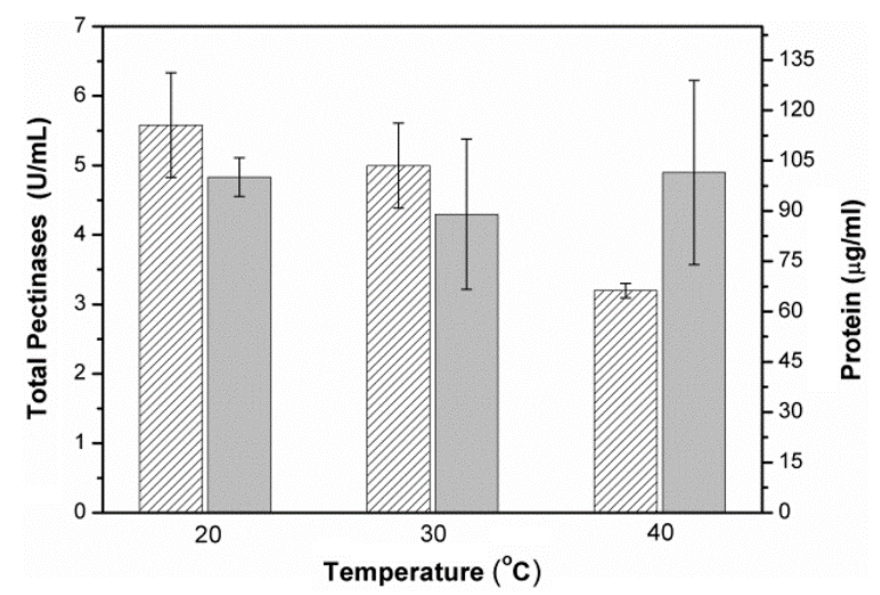

Figure 1. Effect of extraction temperature on total pectinase (TP) activity and protein from solid medium. Solvent, water $\mathrm{pH} 4.0$; incubation time, 60 minutes; $1 / 15$ solid/liquid ratio.

Table 1. Total pectinase (TP) activity recovery with different solid/liquid $(\mathrm{S} / \mathrm{L})$ ratios in the extraction step. Solvent, water $\mathrm{pH} 4.0$; incubation time, 60 minutes; temperature, $20^{\circ} \mathrm{C}$.

\begin{tabular}{ccc}
\hline $\begin{array}{c}{ }^{\mathrm{S}} / \mathrm{L} \\
\left(\mathrm{g} \mathrm{mL}^{-1}\right)\end{array}$ & $\begin{array}{c}\text { TP activity recovered } \\
\left(\mathrm{U} \mathrm{g}^{-1} \text { of dry medium }\right)\end{array}$ & $\begin{array}{c}\text { TP activity solubilized } \\
\left(\mathrm{U} \mathrm{ml}^{-1} \text { solution }\right)\end{array}$ \\
\hline $1 / 45$ & $132.6 \pm 2.3$ & $2.9 \pm 0.05$ \\
$1 / 30$ & $130.2 \pm 20.1$ & $4.3 \pm 0.7$ \\
$1 / 15$ & $114.3 \pm 14.3$ & $7.6 \pm 1$ \\
$1 / 10$ & $108.3 \pm 10.8$ & $10.8 \pm 1.0$ \\
$1 / 7.5$ & $55.7 \pm 3.2$ & $7.4 \pm 0.5$ \\
$1 / 5$ & $22.2 \pm 2.3$ & $4.4 \pm 0.5$ \\
\hline
\end{tabular}

as/L ratio is expressed in dry basis, considering an average moisture of $74 \%$ for the solid medium. polygalacturonase from solid medium and according to these authors, enzyme activity concentration is the best criterion to evaluate the extraction step due to the time and energy savings for the downstream process.

\subsection{Evaluation of pre-treatments of crude pectinase extract}

In order to remove pigments and some proteins produced during the SSC, the crude enzymatic extract was initially treated with activated charcoal $\left(5 \mathrm{~g} \mathrm{~L}^{-1}\right)$. This previous treatment resulted in $72 \%$ and $14 \%$ of color and protein reduction, respectively and $18 \%$ of purification (Table 2) with no loss of TP activity. In a recent work (Dey et al., 2014), a high polygalacturonase purification (34.8 fold), with $69.8 \%$ of enzyme recovery, was described with $10 \mathrm{~g} \mathrm{~mL}^{-1}$ of activated charcoal powder. However, Nakkeeran et al. (2010), observed that the use of $5 \mathrm{~g} \mathrm{~L}^{-1}$ of activated charcoal resulted in the reduction of $83 \%$ of the color of a polygalacturonase preparation, with no significant activity loss.

The activated charcoal-treated enzyme extract was then submitted to microfiltration (MF) to retain impurities that could cause difficulties to the UF recovery step. According to Charcosset (2006), MF can remove polysaccharides, suspended solids, residual cell mass and other particulate debris from liquid suspensions. After MF pre-treatment, almost $94 \%$ of TP activity was recovered and a fold purification of 1.23 was obtained.

\subsection{Assessment of ultrafiltration for the concentration of pectinases and other enzymes}

In the UF, $30 \mathrm{~L}$ of enzyme solution was concentrated, and a volume concentration ratio (VCR) of 103.5 was reached. Figure 2a shows a flux decline of about $58 \%$ after 360 minutes of operation. According to Datta et al. (2009), flux decline in protein separation may be owed to the occurrence of a concentration polarization layer on the membrane surface that leads to increasing resistance to the flux. RodríguezFernández et al. (2013), describe a similar behavior in the concentration of phytase by UF, the flux decline occurring as a consequence of fouling formation and viscosity increment of

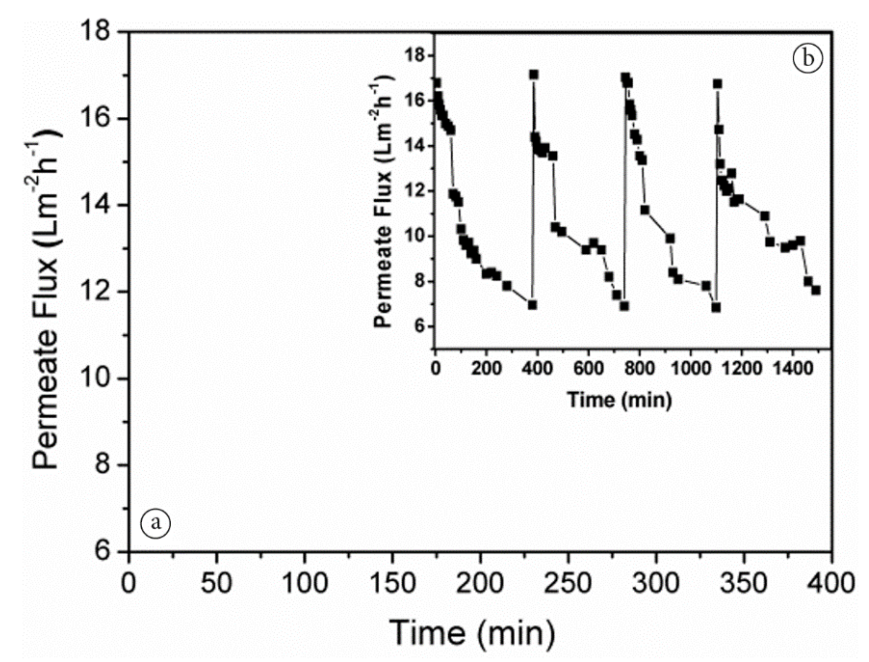

Figure 2. Ultrafiltration of enzymatic extract: (a) permeate flux behavior during 380 minutes; (b) permeate flux behavior after chemical cleaning. 
the feed solution. On the other hand, the UF flux was completely re-established after each chemical cleaning (Figure $2 \mathrm{~b}$ ).

After UF step, TP activity was concentrated 73.6-fold, reaching a final enzyme titer of $663 \mathrm{UmL}^{-1}$, with a recovery yield of $73.7 \%$ (Table 2). Singh et al. (1999), using polysulphone membrane of $30 \mathrm{kDa}$ to concentrate $100 \mathrm{~L}$ of pectinase extract, obtained an activity fold concentration of 50.7 and a recovery yield of 91\%. According to Hwang \& Sz (2011) and Powell \& Timperman (2005), recovery losses are due to surface adsorption and concentration polarization effects on the membrane surface. In addition, recovery of each protein/enzyme is largely dependent on its molecular properties. Rodríguez-Fernández et al. (2013), reported the loss of phytase activity due to the action of shear forces in the UF membrane or conformational changes due to the interaction with membrane during filtration.

UF may be considered as a low resolution purification method in which rejection of molecules is determined by the molecular weight cut off of the membrane. Thus, in our test, enzymes and other proteins with molecular weight above $10 \mathrm{kDa}$ were retained in the concentrate stream and this could explain the low fold purification attained (4.07). This result is in accordance with those of other works that reported values of 5.14 and 7.7 fold purification using membranes with $50 \mathrm{kDa}$ and 10 kDa, respectively (Nakkeeran et al., 2008; Silva et al., 2007). However, the fold purification could be a relatively unimportant parameter for the evaluation of an enzyme recovery method, since the desirable purity degree of a preparation depends on the application. In the case of pectinases, high purity is relatively irrelevant if it is to be applied in the treatment of fruit juices, in which a multicomponent mixture of several enzymes is beneficial to this process. This is in accordance with the description of commercial preparations that consist in a broad spectrum of hydrolytic enzymes.

\subsection{Formulation and stability of final enzyme product}

Commercial enzyme formulations include additives to avoid protein unfolding and to preserve the stability of the enzyme product for several months or years. Glycerol is the most commonly employed additive in pectinolytic enzyme found in the market. Salts in low $(<0.1 \mathrm{M})$ or high $(>0.1 \mathrm{M})$ concentrations are also used to stabilize enzyme preparations (Weijers \& Van't Riet, 1992). Thus, in the present work, glycerol was tested as stabilizing additive at different concentrations: $20 \%, 30 \%, 40 \%$ and $50 \%(\mathrm{w} / \mathrm{w})$. Furthermore, $2 \% \mathrm{w} / \mathrm{v} \mathrm{KCl}$ $(0.34 \mathrm{M})$ was used in all formulations.

Thermostability is an important parameter to determine the application conditions of enzymes. As such, the thermostability of the different formulations was evaluated at 20, 30, 40, 50 and $60^{\circ} \mathrm{C}$ for 60 minutes. Under these conditions, the samples containing different glycerol concentrations presented similar behavior, with approximately the following residual TP activity: $100 \%$ at 20 and $30^{\circ} \mathrm{C}, 85 \%$ at $40^{\circ} \mathrm{C}, 65 \%$ at $50^{\circ} \mathrm{C}$ and $19 \%$ at $60^{\circ} \mathrm{C}$. These results indicate that glycerol has no protective effect for pectinase activity, at least for the time of 60 minutes. The two commercial preparations used as references - Pectinex Ultra SP-L and Novozym 33095 - exhibited 36 and 51\% of the initial TP activity after 60 minutes at $50^{\circ} \mathrm{C}$. Ortega et al. (2004), observed, for the same test conditions, that the preparation Pectinase CCM retained $57 \%$ of its initial activity, whereas only $5 \%$ and $10 \%$ of the initial activities of Rapidase C80 and Pectinex 3XL, respectively, were preserved. These results confirmed that the experimental extract of $A$. niger LB-02-SF has potential to be applied in fruit juices treatment, which is usually carried out at temperatures from 30 to $50^{\circ} \mathrm{C}$.

In the sequence, stability of enzyme formulations during storage was evaluated at $5^{\circ} \mathrm{C}$ for 59 weeks. In the control sample ( $0 \%$ glycerol), it was observed the occurrence of turbidity and precipitate formation, even in the initial weeks of storage, due to the growth of microorganisms as observed by optical microscopy. Otherwise, the samples with glycerol and $\mathrm{KCl}$ did not present turbidity or microbial contamination. After 38 weeks, the control sample presented a decrease in TP activity of $12 \%$ and a decline of $25 \%$ was observed in the last measured (Figure 3 ). The activities in all formulations remained close to $100 \%$ of the initial. In the $50 \%$ glycerol formulation, we observed an activity increase during the storage. Rodríguez-Fernández et al. (2013) described the same increase for phytase activity with $35 \%$ glycerol. The authors related the activation effect with the refolding of the peptide chains and the stabilization of the tertiary and quaternary structures as a result of the hydrogen bonds and other forces created between the enzyme and the glycerol. According to the literature, the enzyme-stabilizing effect of glycerol is due to the following reasons: $i$ ) the positive effect on medium water activity that reduces the possibility of microbial contamination (Iyer \& Ananthanarayan, 2008) and ii) the preferential hydration of proteins that increases structural compaction and disfavor unfolding of proteins (ÓFágáin, 2003). Our results indicate that the use of $20 \%$ glycerol and $2 \% \mathrm{KCl}$ would be enough to ensure the stability of enzyme formulation and so the UF-concentrated extract would be less diluted.

\subsection{Enzymatic clarification of apple and grape juices}

In juice clarification, the commercial enzymes and the experimental formulation (enzyme + glycerol $50 \% \mathrm{w} / \mathrm{w}$ ), further referred as EF, were used in the same dosage. As depicted in Figure 4, apple and grape juice treatment with EF presented

Table 2. Overall results of different steps of recovery of total pectinase (TP) from Aspergillus niger LB-02-SF solid-state cultivation.

\begin{tabular}{lccccccc}
\hline & Volume $(\mathrm{L})$ & $\mathrm{TP}\left(\mathrm{U} \mathrm{mL}^{-1}\right)$ & $\begin{array}{c}\text { Protein } \\
\left.\mathrm{mL}^{-1}\right)\end{array}$ & $\begin{array}{c}\text { Specific activity } \\
\left(\mathrm{U} \mathrm{mg}^{-1}\right)\end{array}$ & $\begin{array}{c}\text { Recovery yield } \\
(\%)\end{array}$ & $\begin{array}{c}\text { Fold activity } \\
\text { concentration }\end{array}$ & $\begin{array}{c}\text { Fold } \\
\text { purification }\end{array}$ \\
\hline Crude extract & 31.1 & 9.0 & 0.33 & 27.6 & - & - & - \\
Activated charcoal & 30.7 & 9.2 & 0.28 & 32.6 & 100 & 1.01 & 1.2 \\
Microfiltration & 30.3 & 8.7 & 0.22 & 40.1 & 93.6 & 0.95 & 1.2 \\
Ultrafiltration & 0.293 & 663 & 4.1 & 163 & 73.7 & 76.2 & 4.1 \\
\hline
\end{tabular}


(a)

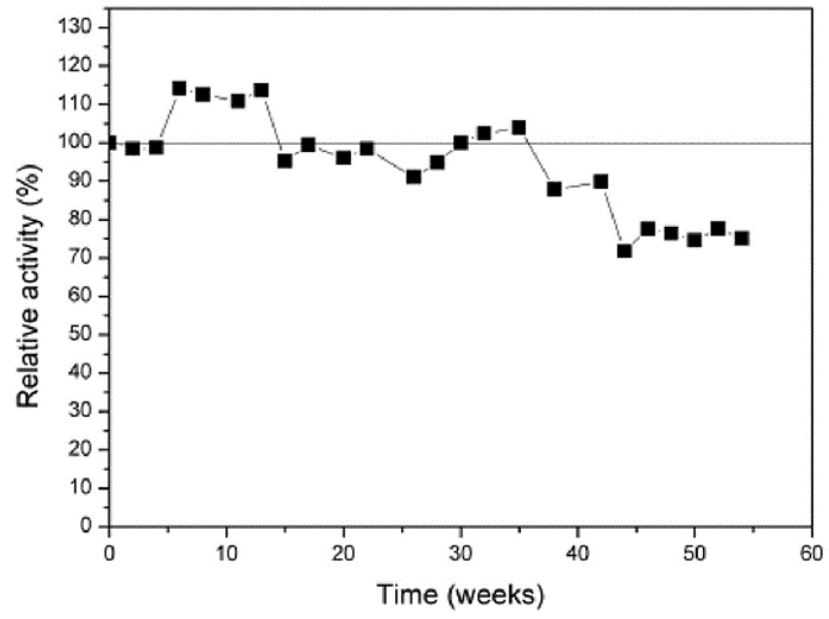

(b)

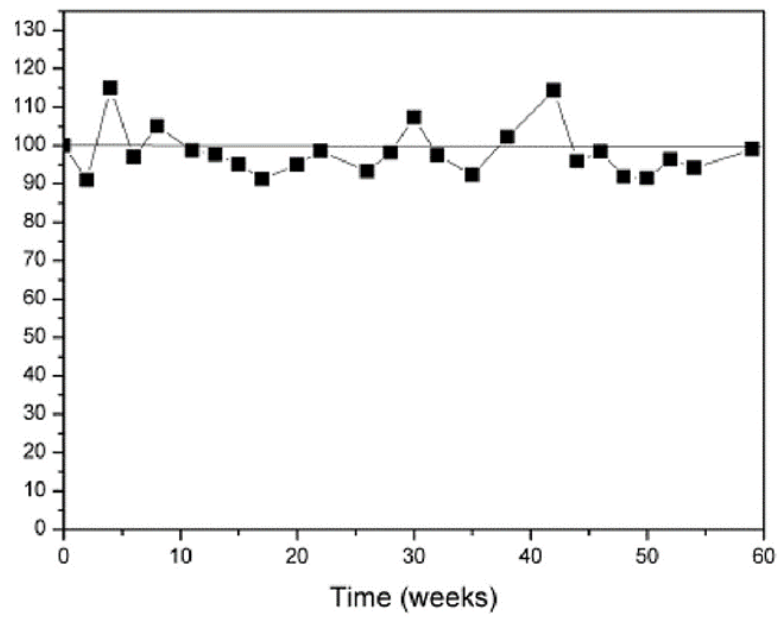

(c)

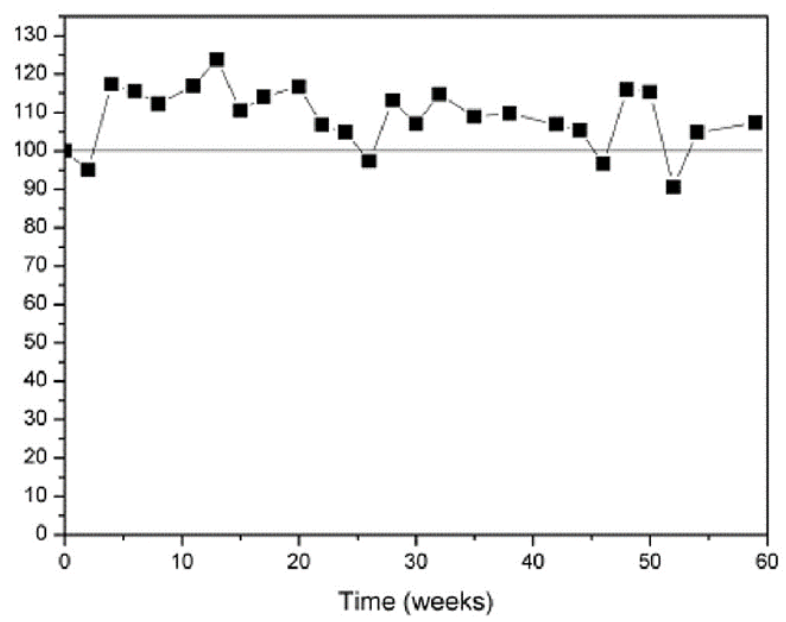

Figure 3. Preservation of pectinase activity during the long-term storage for control sample (a), $20 \%$ (b) and $50 \%$ (c) glycerol formulation at $5^{\circ} \mathrm{C}$.
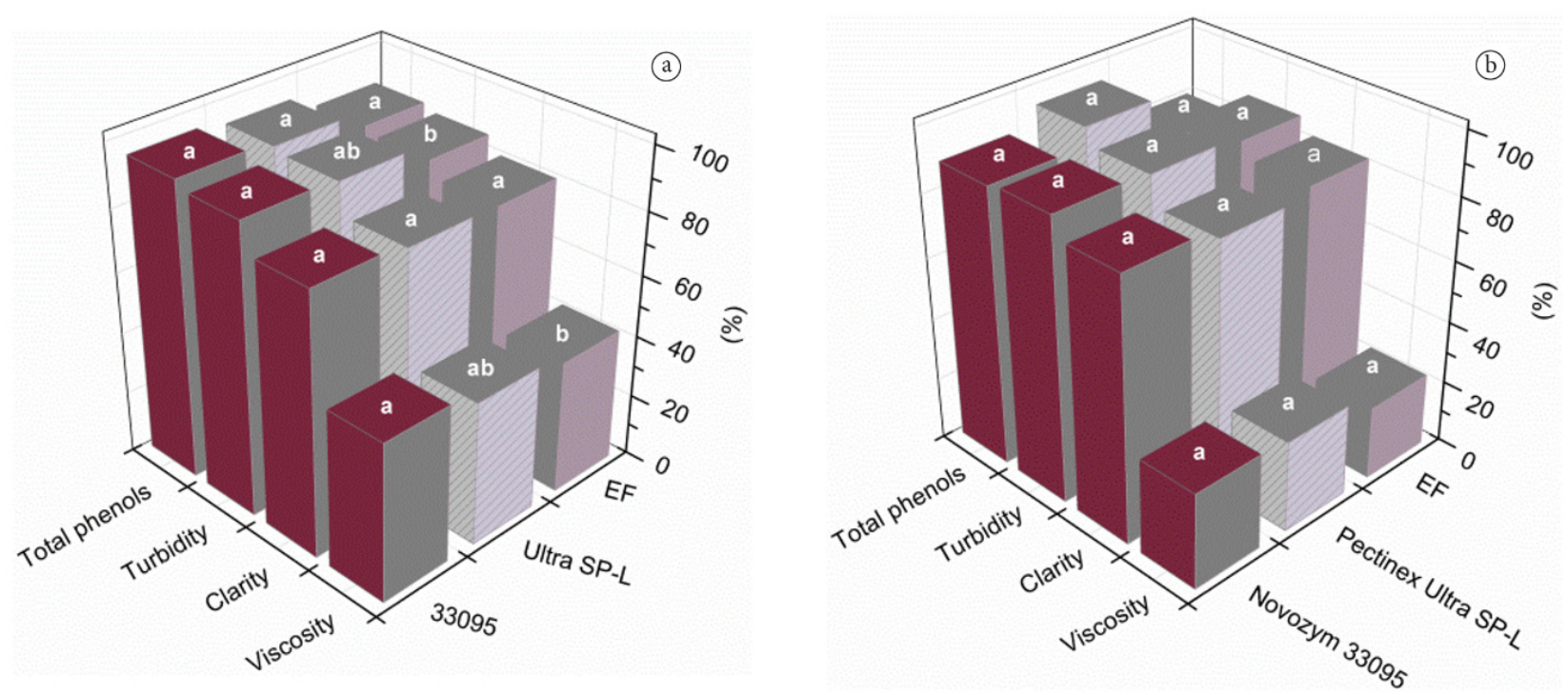

Figure 4. Effect of enzymatic treatment on preservation of total phenol content, decrease of turbidity and viscosity and increase of clarity of apple (a) and grape (b) juices. Commercial enzymes (Novozym 33095 and Pectinex Ultra SP-L) and experimental formulation (EF). Different letters $(\mathrm{a}-\mathrm{c})$ indicate significant differences $(p<0.05)$. The values correspond to the mean of three tests. 
effects on turbidity, viscosity and clarity that were statistically similar to those measured with the commercial enzymes for both juices. According to Pinelo et al. (2010), the clarification of enzyme-treated fruit juices is due to the effect of pectinases on pectic substances which are degraded into small pectin fractions that tend to agglomerate and precipitate.

Total phenol content in both fruit juices was evaluated after the enzyme treatments (Figure 4). These substances are particularly important because of their great health-protecting capacity that relates to their antioxidant activity (Oszmiański et al., 2011). As can be seen, the use of EF did not significantly affect the level of total phenols compared to the commercial enzymes. The results reached with $\mathrm{EF}$ for both juices, confirmed the important role of enzymatic treatment in the hydrolysis of pectin-containing beverages.

\section{Conclusions}

The results obtained in bench scale in this work may be useful for scaling up the steps of recovery and concentration of enzymes produced by A. niger LB-02-SF in solid-state cultivation. The protocol proposed led to a downstream processing with high enzyme recovery in a few steps. The results of storage stability and performance in fruit juices treatment suggest a great potential for a future commercialization of the experimental enzyme formulation.

\section{Acknowledgements}

This study was supported by grants from the Conselho Nacional de Desenvolvimento Científico e Tecnológico (CNPq, Brazil), the Fundação de Amparo à Pesquisa do Estado do Rio Grande do Sul (FAPERGS, Brazil) and the Coordenadoria de Aperfeiçoamento de Pessoal de Nível Superior (CAPES, Brazil).

\section{References}

Bradford, M. M. (1976). A rapid and sensitive method for the quantitation of microgram quantities of protein utilizing the principle of proteindye binding. Analytical Biochemistry, 72(1-2), 248-254. http://dx.doi. org/10.1016/0003-2697(76)90527-3. PMid:942051

Castilho, L. R., Medronho, R., \& Alves, T. L. M. (2000). Production and extraction of pectinases obtained by solid state fermentation of agroindustrial residues with Aspergillus niger. Bioresource Technology, 71(1), 45-50. http://dx.doi.org/10.1016/S0960-8524(99)00058-9.

Charcosset, C. (2006). Membrane processes in biotechnology: an overview. Biotechnology Advances, 24(5), 482-492. http://dx.doi. org/10.1016/j.biotechadv.2006.03.002. PMid:16687233

Cheryan, M. (1998). Ultrafiltration and microfiltration: handbook(2nd ed.). Boca Raton, EUA: CRC Press. 527 p.

Datta, D., Bhattacharjee, S., Nath, A., Das, R., Bhattacharjee, C., \& Datta, S. (2009). Separation of ovalbumin from chicken egg white using two-stage ultrafiltration technique. Separation and Purification Technology, 66(2), 353-361. http://dx.doi.org/10.1016/j. seppur.2008.12.016.

Dey, T. B., Adak, S., Bhattacharya, P., \& Banerjee, R. (2014). Purification of polygalacturonase from Aspergillus awamori Nakazawa MTCC 6652 and its application in apple juice clarification. LWT - Food Science and Technology, 59(1), 591-595. http://dx.doi.org/10.1016/j. lwt.2014.04.064.
Díaz, A. B., Caro, I., de Ory, I., \& Blandino, A. (2007). Evaluation of the conditions for the extraction of hydrolitic enzymes obtained by solid state fermentation from grape pomace. Enzyme and Microbial Technology, 41(3), 302-306. http://dx.doi.org/10.1016/j. enzmictec.2007.02.006.

European Commission. Federal Environment Agency Austria. InterUniversity Research Center for Technology, Work and the Culture (2002). Final Report: Collection of Information on Enzymes. Contract no. B4-3040/2000/278245/MAR/E2. Luxembourg: Office for Official Publications of the European Communities.

Fontana, R. C., Salvador, S., \& Silveira, M. M. (2005). Influence of pectin and glucose on growth and polygalacturonase production by Aspergillus niger in solid-state cultivation. Journal of Industrial Microbiology \& Biotechnology, 32(8), 371-377. http://dx.doi. org/10.1007/s10295-005-0004-0. PMid:16059783

Gainvors, A., Nedjaoum, N., Gognies, S., Muzart, M., Nedjma, M., \& Belarbi, A. (2000). Purification and characterization of acidic endopolygalacturonase encoded by the PGL1-1 gene from Saccharomyces cerevisiae. FEMS Microbiology Letters, 183(1), 131-135. http://dx.doi. org/10.1111/j.1574-6968.2000.tb08946.x. PMid:10650215

Gummadi, S. N., \& Panda, T. (2003). Purification and biochemical properties of microbial pectinases - a review. Process Biochemistry, 38(7), 987-996. http://dx.doi.org/10.1016/S0032-9592(02)00203-0.

Hendges, D. H., Montanari, Q., Malvessi, E., \& Silveira, M. M. (2011). Production and characterization of endo-polygalacturonase from aspergillus niger in solid-state fermentation in double-surface bioreactor. Brazilian Archives of Biology and Technology, 54(2), 253-258. http://dx.doi.org/10.1590/S1516-89132011000200005.

Hwang, K.-J., \& Sz, P.-Y. (2011). Membrane fouling mechanism and concentration effect in cross-flow microfiltration of BSA/dextran mixtures. Chemical Engineering Journal, 166(2), 669-677. http:// dx.doi.org/10.1016/j.cej.2010.11.044.

Iyer, P. V., \& Ananthanarayan, L. (2008). Enzyme stability and stabilization-Aqueous and non-aqueous environment. Process Biochemistry, 43(10), 1019-1032. http://dx.doi.org/10.1016/j. procbio.2008.06.004.

Jayani, R. S., Saxena, S., \& Gupta, R. (2005). Microbial pectinolytic enzymes - a review. Process Biochemistry, 40(9), 2931-2944. http:// dx.doi.org/10.1016/j.procbio.2005.03.026.

Maciel, M. D. H. C., Ottoni, C. A., Herculano, P. N., Porto, T. S., Porto, A. L. F., Santos, C., Lima, N., Moreira, K. A., \& Souza-Motta, C. (2014). Purification of polygalacturonases produced by Aspergillus niger using an aqueous two-phase system. Fluid Phase Equilibria, 371, 125-130. http://dx.doi.org/10.1016/j.fluid.2014.03.018.

Mohsen, S. M., Bazaraa, W. A., \& Doukani, K. (2009). Purification and characterization of Aspergillus niger U-86 polygalacturonase and its use in clarification of pomegranate and grape juices. In Proceedings of the 4th Conference on Recent Technologies in Agriculture, Cairo, Giza, Egypt.

Nakkeeran, E., Subramanian, R., \& Umesh Kumar, S. (2008). Improving specific activity of Aspergillus carbonarius polygalacturonase using polymeric membranes. Applied Biochemistry and Biotechnology, 151(2-3), 233-243. http://dx.doi.org/10.1007/s12010-008-8182-7. PMid:18357418

Nakkeeran, E., Subramanian, R., \& Umesh-Kumar, S. (2010). Purification of polygalacturonase from solid-state cultures of Aspergillus carbonarius. Journal of Bioscience and Bioengineering, 109(2), 101106. http://dx.doi.org/10.1016/j.jbiosc.2009.08.005. PMid:20129091

O’Fágáin, C. (2003). Enzyme stabilization-recent experimental progress. Enzyme and Microbial Technology, 33(2-3), 137-149. http://dx.doi. org/10.1016/S0141-0229(03)00160-1. 
Ortega, N., De Diego, S., Perez-Mateos, M., \& Busto, M. D. (2004). Kinetic properties and thermal behaviour of polygalacturonase used in fruit juice clarification. Food Chemistry, 88(2), 209-217. http:// dx.doi.org/10.1016/j.foodchem.2004.01.035.

Oszmiański, J., Wojdyło, A., \& Kolniak, J. (2011). Effect of pectinase treatment on extraction of antioxidant phenols from pomace, for the production of puree-enriched cloudy apple juices. Food Chemistry, 127(2), 623-631. http://dx.doi.org/10.1016/j.foodchem.2011.01.056. PMid:23140709

Pinelo, M., Zeuner, B., \& Meyer, A. S. (2010). Juice clarification by protease and pectinase treatments indicates new roles of pectin and protein in cherry juice turbidity. Food and Bioproducts Processing, 88(2-3), 259-265. http://dx.doi.org/10.1016/j.fbp.2009.03.005.

Powell, M. J., \& Timperman, A. T. (2005). Quantitative analysis of protein recovery from dilute, large volume samples by tangential flow ultrafiltration. Journal of Membrane Science, 252(1-2), 227-236. http://dx.doi.org/10.1016/j.memsci.2004.12.024.

Rangana, S. (1977). Manual of analysis of fruit and vegetable products. New Delhi: Tata McGraw Hill Publishing Company. 634 p.

Rodríguez-Fernández, D. E., Léon, J. A. R., Carvalho, J. C., Karp, S. G., Parada, J. L., \& Soccol, C. R. (2012). Process development to recover pectinases produced by solid-state fermentation. Journal of Bioprocessing \& Biotechniques, 2(4). http://dx.doi.org/10.4172/21559821.1000121.

Rodríguez-Fernández, D. E., Parada, J. L., Medeiros, A. B. P., de Carvalho, J. C., Lacerda, L. G., Rodríguez-León, J. A., \& Soccol, C. R. (2013).
Concentration by ultrafiltration and stabilization of phytase produced by solid-state fermentation. Process Biochemistry, 48(2), 374-379. http://dx.doi.org/10.1016/j.procbio.2012.12.021.

Sandri, I. G., Lorenzoni, C. M. T., Fontana, R. C., \& da Silveira, M. M. (2013). Use of pectinases produced by a new strain of Aspergillus niger for the enzymatic treatment of apple and blueberry juice. LWT - Food Science and Technology, 51(2), 469-475. http://dx.doi. org/10.1016/j.lwt.2012.10.015.

Silva, D., Martins, E. S., Leite, R. S. R., Da Silva, R., Ferreira, V., \& Gomes, E. (2007). Purification and characterization of an exopolygalacturonase produced by Penicillium viridicatum RFC3 in solid-state fermentation. Process Biochemistry, 42(8), 1237-1243. http://dx.doi.org/10.1016/j.procbio.2007.05.025.

Singh, S. A., Ramakrishna, M., \& Appu Rao, A. G. (1999). Optimisation of downstream processing parameters for the recovery of pectinase from the fermented bran of Aspergillus carbonarius. Process Biochemistry, 35(3-4), 411-417. http://dx.doi.org/10.1016/S0032-9592(99)00089-8.

Singleton, V. L., \& Rossi, J. A. (1965). Colorimetry of total phenolics with phosphomolybdic-phosphotungstic acid reagent. American Journal of Enology and Viticulture, 16, 144-158.

Weijers, S. R., \& Van't Riet, K. (1992). Enzyme stability in downstream processing part 1: enzyme inactivation, stability and stabilization. Biotechnology Advances, 10(2), 237-249. http://dx.doi.org/10.1016/07349750(92)90004-S. 